Peer Reviewed Article

ISSN: 2162-3104 Print/ ISSN: 2166-3750 Online Volume 7, Issue 4 (2017), pp. 1126-1134

(C) Journal of International Students

http://jistudents.org/

doi: $10.5281 /$ zenodo. 1035979

\title{
Troubling Metaphors and International Student Adjustment: Reflections from a Transnational Place
}

\author{
David Starr-Glass \\ SUNY Empire State College, International Programs (Prague)
}

\begin{abstract}
On many campuses, offices of International Student Affairs address the perceived needs of international students. However, a number of underlying assumptions and persistent metaphors shape these efforts and influence their outcomes. All students are uniquely different and face equally different challenges in adjusting to higher education. Labeling students "international" may make institutional sense, but it can potentially hinder their transition, adjustment, and ultimate success. Applying restrictive labels can perpetuate stereotypes, reinforce institutional silos, and potentially fracture international students from the rest of the student body. This article reflects on how students-irrespective of national origins-are viewed and assisted in a transnational setting that includes more than $70 \%$ of students who might, in other contexts, be classified as "international."
\end{abstract}

Keywords: cultural capital, inclusion, integration, labeling theory, perceived difference, self-identity, stereotyping

A key issue at many institutions of higher education is the adjustment and success of their international students. It is well recognized that inbound educational migrants often confront challenges in adjusting to their new country and its educational system, and that they may face problems in integrating with the domestic student body (Gebhard, 2012; Vasilopoulos, 2016). Although some college administrations and faculties provide wellintentioned assistance, the adjustment experience of many international 
students indicates that significant barriers and difficulties still exist. Of course all adjustments can be complex and difficult, but it is suggested that part of the difficulty faced by international students lies in how their colleges perceive them and respond to them based on those perceptions (Roberston, Line, Jones, \& Thomas, 2000).

This practitioner-based reflection starts with an exploration of two metaphors that are central to the problem. However, at the outset, it might be helpful to clarify several issues: (a) although conceptual metaphors may seem like rhetorical flourishes, they have the power to shape "the way we think, what we experience, and what we do every day" (Lakoff \& Johnson, 1980 , p. 3); and (b) when metaphors are recognized and taken seriously, they have "the ability rearrange the furniture of the mind" (Kittay, 1995). This reflection considers two troubling metaphors and attempts to rearrange the mental furniture that we might have accumulated about international students, their adjustment, and their success.

\section{LABEL METAPHORS: AUTHENTIC IDENTITY AND STEREOTYPE}

We may not literally attach labels, but we do metaphorically label the world around us. Labels allow us to recognize, categorize, and make sense of what might otherwise be a confusing and disorientating world. Labeling is an active and intuitive process - a reflexive sense-making heuristic - that provides utility, but it also creates and perpetuates stereotypes that can blind us and negatively impact those who are labeled. There is ample evidence from labeling theory, attribution theory, and intuitive judgment research to indicate that labels - when differentially applied and reinforced through usage - significantly shape our perceptions of others, change our behavior towards them, and impact their self-identities and self-definitions (Heckert \& Heckert, 2010; Kahneman, 2002; Malle, 2011).

Labeling does not automatically impose an identity, but it does provide a starting point when we try to make sense of the other. It also provides a less than helpful starting place for those others when they begin to consider their own identities, generate self-narratives, and negotiate a discourse of identity (Haugh, 2008). In this reflection, it is argued that to be labeled an "international student" is to be identified as something different and distinct from a "domestic" student. Thus labeled, international students are casually relegated to a homogenous group in ways that might be 
institutionally helpful, but which promote stereotypes, obscure diversity, and contribute to a slow erosion of individual selfhood (Scudamore, 2013).

All students have individual needs and face unique challenges when they enter college. For example, in U.S. higher education, more than $30 \%$ of all first- and second-year domestic students enroll in remedial courses to address specific learning and academic problems (Chen \& Simone, 2016). Many students - domestic and international-are challenged by the culture of their institution, by the dynamics of the learning process, and their inability to communicate effectively. Further, most students - if not all students-would welcome richer educational experiences and greater exposure to different perspectives in the classroom and on campus. But how can that richness and diversity materialize if those who are the most likely to provide it feel separated and segregated by the "international" label? How can those students contribute to the social and cultural richness of the institution if they sense that they are classed as different and that the most prudent response to that difference is social silence or invisibility?

\section{SILO METAPHORS: PART-OBJECTS AND INSTITUTIONAL MYOPIA}

Grain silos are storage towers that hold one type of grain and segregate it from others - they isolate the particular, prevent mixing, and function to conserve separate identities. Clearly, silos provide a rich set of attributes that can be metaphorically mapped onto seemingly unrelated situations, behaviors, and states of mind. In particular, silo metaphors have been used to describe the way in which some organizational participants come to perceive themselves as separated from the broader organization, consider themselves isolated from its central mission, and - often unintentionally and quite unconsciously - start to treat others as what some have termed "disconnected part-objects" (Cilliers \& Greyvenstein, 2012).

At the individual level, silos produce a mindset that is so exclusively focused on the particular that individuals gradually become unaware - and often quite unconcerned - about the relationship between that specific element and the larger organizational picture. Silos, and those who occupy them, create barriers to the comprehensive operational integration, information sharing, and regenerative creativity that are needed throughout the whole organization. Once erected, silos have a remarkable ability to persist at all levels - cultural, cognitive, and behavioral (Willcock, 2014). 
Most colleges and universities are organized functionally and have limited structural features that allow for the development of departmental cross-linkage or administrative integration. As such, it seems natural that, once a college labels a part of its student population "international," it will then create a functional unit to deal with this designated sectorInternational Student Affairs. These organizational units address the issues that are perceived as relevant for the adjustment, transition, and success of those labeled "internationals" (Lillyman \& Bennett, 2014; Long, 2012; Manning, Kinzie, \& Schuh, 2014; Schuh, Jones, \& Harper, 2011). Offices of International Student Affairs can be seen as performing a very useful function, but all too easily-incrementally and unwittingly - they can also become isolated silos with unnecessarily restricted remits, overly focused objectives, and behaviors continuously reinforced by pragmatism and myopia about international students.

\section{WHERE INTERNATIONAL STUDENTS ARE SIMPLY STUDENTS}

As an educator practicing in international settings, I have been concerned about the impact of stereotypical labeling and restrictive silos on student outcomes. My initial concern was that the conceptual metaphors of labels and silos become reified and start to impose limits on how we understand international students and on how we work with them. My deeper concern is that the well-intentioned classification of students as international-and the equally well-intentioned efforts of International Student Affairs-are essentially counterproductive and often inhibit the adjustment, integration, and academic success of the students involved. Since these concerns are shaped by my own experiences, it might be useful to provide some context.

I supervise students researching and writing their undergraduate dissertations at an International Program of an accredited American college. The college has established an educational alliance with a private university in Prague, the Czech Republic. The college determines curriculum, monitors the delivery of educational experiences, and maintains an on-site presence to ensure academic quality control. At first glance, this might seem to be a classic example of transnational education, an arrangement through which students who are citizens of one country enroll in-and subsequently receive academic credits and qualifications from-a higher education institution located in a different country (O'Mahony, 2014; Ziguras \& McBurnie, 2015). However, the situation and dynamics are more complex. 
In most transnational education settings, the majority of enrolled students are from the local country. In Prague, the situation is different. The college has a stellar reputation for educational excellence and for graduate placement and success. This well-deserved reputation attracts highly qualified applicants not only from the Czech Republic, but also from many neighboring Central and Eastern European countries, Russia, and the Asian republics of the former USSR. Consequently, although Czech students form the single largest national group on campus, they only constitute $28 \%$ of the undergraduate population. The campus has exceptional national diversity, with 2016 statistics showing that our 550 students come from no less than sixty different countries.

This truly remarkable degree of national representation gives the campus an exceptionally rich, vibrant, and exciting mix of cultures and languages. Our campus is the epitome of an international academic community; indeed, the adjective "international" seems insipid, redundant, and quite irrelevant. In a very real sense, we have no international students. Every student is simply recognized as a student, and every studentirrespective of ethnic or national culture heritage - is regarded as an equally privileged member of our learning community.

Given this context, we also have no International Students Affairs office on campus. Student advisement, educational guidance, learning assistance, and appropriate remediation are provided for all students based on individual need, not on place of origin. We recognize every student as a unique individual and provide services and assistance for him/her as a person, not as a representative of a domestic or foreign group. In our institutional lexicon, there is neither room nor reason for words such as domestic, native-born, foreign, or international.

Indeed, in my conversations with students they rarely self-identify as international; instead, they understand themselves to be students in an international setting. If they have issues with their English language skills, they sign up for workshops in which they may sit beside native Englishspeakers - the focus is on a shared problem, not on a different place of origin. In fact, on our campus the only international label is attached to a department that deals with visa requirements and European educational transfer opportunities (Erasmus).

This situation may be exceptional, but it is what we have created and it is what we and our students experience. It suggests alternative ways of thinking about nationally migrant students, about how they might be helped to adjust, and about how they might be assisted to succeed. By 
labeling individuals as international, we might inadvertently be setting them up to experience the anticipated difficulties common to "international students." By labeling them, they might be seen - and might come to see themselves - as different in ways that are as false as they are unhelpful. By focusing too much on presumed difference, we might be neglecting the commonalities that all students share, no matter from where they come.

By automatically applying international labels, we might be segregating and unwittingly placing obstacles in paths to success. And by delegating the responsibility of inbound students to the silos of International Student Affairs, we might be distancing them and pushing them away from the broader academic community to which they rightly belong. This is not to claim that International Student Affairs has no place on campus. Rather, it is to suggest that it might be more useful to integrate their services into other student support systems, to absorb some of their specialist functions into more general programs and initiatives, and to deliberately reduce the perceived institutional boundaries that separate visiting students from their domestically-based peers.

Unfortunately, in many institutions of higher education in the United States, it is all too common for international students to be in demand primarily because they provide a source of higher tuition: international students have spawned an industry. Colleges need to be more mindful of the value of inbound migrant students, because these students bring more than money - they bring a richness of creative diversity and a wealth of much-needed cultural capital. Colleges also need to be more appreciative of the social and cultural wealth associated with these students and of how that wealth can contribute to "the development of... equality and diversity awareness, knowledge and skill within students and staff that can lead to cultural and societal change" (Hanesworth, 2016, p. 2).

Deeper insights into diversity, national culture, and international difference - all perspectives increasingly prized by academic institutions and needed by their graduates - can only come about if inbound migrant students are regarded as true partners (Hudzik, 2015). Critically, higher education needs to realize that "culturally inclusive pedagogies shift responsibility for inclusion from the learner to the educational institution" (Blasco, 2015, p. 86). Incoming educational migrants are valuable institutional resources, not administrative challenges. They need to be accepted as valuable agents of change, not as marginalized objects to change. They need to be acknowledged as students who are an integral 
component of the academy, not labeled as international students who are in some way separate, exceptional, or problematically different.

In looking forward, it might be helpful to remember, "the living metaphor starts dying once it begins to live within language" (Billig \& MacMillan, 2005, p. 461). Perhaps, in time, the metaphoric labels pinned onto our international students might become less restrictive and increasingly irrelevant. To create more vibrant campuses, in which all students can grow and learn, we need to accept incoming students-who are often mentally courageous, motivated, and adventurous - as peers and fellow students, not as differentiated internationals.

To allow all students to grow-irrespective of their cultural and national origins - we need to reconfigure the dedicated silos designed to serve only those who are perceived as different, or who are considered temporary sojourners on our campuses. And to bring about richer, more stimulating, and more inclusive communities of learning we need to provide appropriate care and assistance-not circumscribed by place of birth or predicated on perceptions of difference - to all who wish to advance, integrate, and succeed in those communities.

\section{REFERENCES}

Billig, M., \& MacMillan, K. (2005). Metaphor, idiom and ideology: The search for no smoking guns across time. Discourse and Society, 16(4), 459-480.

Blasco, M. (2015). Making the tacit explicit: Rethinking culturally inclusive pedagogy in international student academic adjustment. Pedagogy, Culture \& Society, 23(1), 85-106.

Chen, X., \& Simone, S. (2016). Remedial coursetaking at U.S. public 2- and 4-year institutions: Scope, experiences, and outcomes (NCES 2016-405). U.S. Department of Education. Washington, DC: National Center for Education Statistics. Retrieved from http://nces.ed.gov/pubs2016/2016405.pdf

Cilliers, F., \& Greyvenstein, H. (2012). The impact of silo mentality on team identity: An organisational case study. SA Journal of Industrial Psychology/SA Tydskrif vir Bedryfsielkunde, 38(2), Article 993. Retrieved from http://www.sajip.co.za/index.php/sajip/article/viewPDFInterstitial/ $993 / 1179$

Gebhard, J. G. (2012). International students' adjustment problems and behaviors. Journal of International Students, 2(2), 184-193.

Hanesworth, P. (Ed.) (2016). Introduction. Equality and diversity in learning and teaching in higher education, Equality Challenge Unit and Higher Education Academy joint conference, Edinburgh, Scotland. Retrieved from 
http://www.ecu.ac.uk/wp-content/uploads/2016/03/Equality-and-diversityin-learning-and-teaching-Full-report.pdf

Haugh, M. (2008). The discursive negotiation of international student identities. Discourse: Studies in the Cultural Politics of Education, 29(2), 207-222.

Heckert, A., \& Heckert, D. (2010). Differential labeling theory. Sociological Imagination, 46(1), 24-40.

Hudzik, J. K. (2015). Comprehensive internationalization: Institutional pathways to success. London, UK: Routledge.

Kahneman, D. (2002). Maps of bounded rationality: A perspective on intuitive judgment and choice. Nobel Prize Lectures, Stockholm, December 8 (pp. 449-489). Retrieved from www.nobelprize.org/nobel_prizes/economicsciences/laureates/2002/kahnemann-lecture.pdf

Kittay, E. F. (1995). Metaphor as rearranging the furniture of the minds: A reply to Donald Davidson's "What metaphors mean." In Z. Radman (Ed.), From a metaphorical point of view: A multidisciplinary approach to the cognitive content of metaphor (pp. 73-116). Berlin, Germany: Walter de Gruyter.

Lakoff, G., \& Johnson, M. (1980). Metaphors we live by. Chicago, IL: Chicago University Press.

Lillyman, S., \& Bennett, C. (2014). Providing a positive learning experience for international students studying at UK universities: A literature review. Journal of Research in International Education, 13(1), 63-75.

Long, D. (2012). The foundations of student affairs: A guide to the profession. In L. J. Hinchliffe \& M. A. Wong (Eds.), Environments for student growth and development: Librarians and student affairs in collaboration (pp. 1-39). Chicago, IL: Association of College and Research Libraries.

Malle, B. F. (2011). Attribution theories: How people make sense of behavior. In D. Chadee (Ed.), Theories in social psychology (pp. 72-95). Oxford, UK: Wiley-Blackwell.

Manning, K., Kinzie, J., \& Schuh, J. H. (2014). One size does not fit all: Traditional and innovative models of student affairs practice $\left(2^{\text {nd }}\right.$ ed.). New York, NY: Routledge.

Roberston, M., Line, M., Jones, S., \& Thomas, S. (2000). International students, learning environments and perceptions: A case study using the Delphi technique. Higher Education and Development, 19(1), 89-102.

Schuh, J. H., Jones, S. R., \& Harper, S. R. (Eds.) (2011). Student services: A handbook for the profession $\left(5^{\text {th }}\right.$ ed.). New York, NY: John Wiley.

O'Mahony, J. (2014). Enhancing student learning and teacher development in transnational education. York, UK: Higher Education Academy. Retrieved from: https:/www.heacademy.ac.uk/system/files/resources/enhancingtne final_080414.pdf

Scudamore, R. (2013). Engaging home and international students: A guide for new lecturers. York, UK: Higher Education Academy. Retrieved from: 
https://www.heacademy.ac.uk/system/files/rachelscudamorereportfeb2013. pdf

Vasilopoulos, G. (2016). A critical review of international students' adjustment research from a Deleuzian perspective. Journal of International Students, 6(1), 283-307.

Willcock, D. (2014). Inside-out collaboration. Reflections, 14(3), 13-22.

Ziguras, C., \& McBurnie, G. (2015). Governing cross-border higher education. London, UK: Routledge.

DAVID STARR-GLASS is a mentor and undergraduate dissertation supervisor with the International Programs (Prague) of SUNY Empire State College. David has earned three master's degrees: business administration, organizational psychology, and education. His teaching and research interests include mentoring, organizational culture, and cross-cultural management and over the last twenty years he has published more than seventy peer-reviewed articles and book chapters. When not in Prague, David lives in Jerusalem where he teaches economic and business-related courses with a number of local colleges. E-mail: David.Starr-Glass@esc.edu 